\title{
The Federal Response to Home Mortgage Distress: Lessons from the Great Depression
}

\author{
David C. Wheelock
}

\begin{abstract}
This article examines the federal response to mortgage distress during the Great Depression: It documents features of the housing cycle of the 1920s and early 1930s, focusing on the growth of mortgage debt and the subsequent sharp increase in mortgage defaults and foreclosures during the Depression. It summarizes the major federal initiatives to reduce foreclosures and reform mortgage market practices, focusing especially on the activities of the Home Owners' Loan Corporation (HOLC), which acquired and refinanced one million delinquent mortgages between 1933 and 1936. Because the conditions under which the HOLC operated were unusual, the author cautions against drawing strong policy lessons from the HOLC's activities. Nonetheless, similarities between the Great Depression and the recent episode suggest that a review of the historical experience can provide insights about alternative policies to relieve mortgage distress. (JEL E44, G21, G28, N12, N21)
\end{abstract}

Federal Reserve Bank of St. Louis Review, May/June 2008, 90(3, Part 1), pp. 133-48.

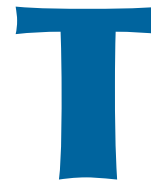

he growth in U.S. house prices peaked in 2005 and has since fallen rapidly. By late 2006, a national index began to show an outright decline in U.S. house prices, and some analysts forecast that prices could fall 10 percent or more nationally. ${ }^{1}$ Mortgage delinquencies and foreclosures have risen sharply as the growth in house prices has slowed. As of the fourth quarter of 2007, 3.6 percent of residential mortgages, 14.4 percent of subprime

1 In an August 2005 interview, Robert Shiller predicted U.S. house prices could fall by 40 percent (Leonhardt, 2005). The S\&P/CaseShiller U.S. National Home Price Index began to fall in the third quarter of 2006. The house price index for purchase transactions produced by the Office of Federal Housing Enterprise Oversight (OFHEO) declined for the first time (since 1993) in the third quarter of 2007. The OFHEO index is based on data for mortgages purchased by Fannie Mae and Freddie Mac, two large governmentsponsored enterprises that purchase and securitize home mortgages valued below a conforming limit, which in 2007 was $\$ 417,000$. The $\mathrm{S} \& \mathrm{P} /$ Case-Shiller index is based on data that include mortgages that exceed this limit; it thereby includes data on more-expensive homes that nationally have tended to show more-rapid price appreciation followed by more-rapid depreciation during the recent cycle than less-expensive homes. mortgages, and 20.4 percent of adjustable-rate subprime mortgages were seriously delinquent (i.e., with payments at least 90 days past due or in foreclosure). In that quarter, 0.9 percent of all mortgages, 3.7 percent of subprime mortgages, and 5.7 percent of adjustable-rate subprime mortgages entered the foreclosure process. ${ }^{2}$ Many analysts predict that house prices will continue to fall and that mortgage delinquency and foreclosure rates will remain high until 2009 or beyond.

The severe distress in housing and mortgage markets has prompted numerous proposals to stem the tide of loan defaults and foreclosures. Government officials have encouraged lenders to modify the terms of existing loans to reduce loan payments and thereby lower default rates, while

\footnotetext{
2 By contrast, less than 2 percent of all residential mortgages and less than 6 percent of subprime mortgages were seriously delinquent during 2005, when just 0.4 percent of all residential mortgages and 1.5 percent of all subprime mortgages entered foreclosure. These are non-seasonally adjusted data from the Mortgage Bankers Association (Haver Analytics).
}

David C. Wheelock is an assistant vice president and economist at the Federal Reserve Bank of St. Louis. The author thanks William Emmons and Tom Garrett for comments on a prior draft. Craig P. Aubuchon provided research assistance.

(C) 2008, The Federal Reserve Bank of St. Louis. Articles may be reprinted, reproduced, published, distributed, displayed, and transmitted in their entirety if copyright notice, author name(s), and full citation are included. Abstracts, synopses, and other derivative works may be made only with prior written permission of the Federal Reserve Bank of St. Louis. 
the Federal Reserve has proposed new regulations to limit mortgage market practices that many observers believe have contributed to high default rates. ${ }^{3}$ The Bush administration authorized expanded use of Federal Housing Administration (FHA) guarantees to refinance subprime home mortgages and requested legislation to raise FHA loan limits and ease down payment requirements for FHA-guaranteed loans. ${ }^{4}$ Other proposals on the table include (i) directing Fannie Mae and Freddie Mac, the two main government-sponsored enterprises that purchase and securitize home mortgages, to refinance subprime mortgages; (ii) permitting states to refinance loans at risk of foreclosure through the issuance of federal tax-exempt mortgage revenue bonds; and (iii) creating a new federal corporation to purchase distressed mortgages from investors and convert them to 30-year fixed-rate mortgages. ${ }^{5}$

The creation of a new federal corporation to purchase distressed mortgages would mimic a similar agency, the Home Owners' Loan Corporation (HOLC), that was established to purchase delinquent home mortgages during the Great Depression. Many observers have noted that the recent increase in home mortgage defaults resembles the experience of the Great Depression, when a tidal wave of home mortgage defaults also occurred. This article takes a look back at the Great Depression experience and identifies differences and similarities with the current episode. As with the current episode, the increase in mortgage defaults during the Depression was preceded by a period of extensive home building and rising house prices and an increasing use of debt to

\footnotetext{
3 The Federal Reserve proposal is summarized in a press release dated December 18, 2007: www.federalreserve.gov/newsevents/ press/bcreg/20071218a.htm.

4 Details of the Administration's proposals in response to the subprime mortgage crisis are described in a speech by Treasury Secretary Paulson on December 3, 2007: www.ustreas.gov/press/ releases/hp706.htm.

5 Senator Charles Schumer proposed (i) and (ii) in remarks entitled "A Call to Action on the Subprime Mortgage Crisis: Putting Common Sense Ahead of Ideology," delivered at the Brookings Institution on December 19, 2007. Proposals for the creation of a Federal Homeownership Preservation Corporation were discussed in hearings before the U.S. Senate Banking Committee on January 31, 2008. See Barr (2008) and Pollock (2008).
}

finance house purchases. Defaults rose sharply in the early 1930s when house prices and household incomes collapsed. The tidal wave of mortgage defaults and foreclosures prompted calls for government help, and the federal government, as well as state and local governments, responded quickly with a variety of programs to alleviate the distress in mortgage markets.

This article first documents features of the housing boom of the 1920s and describes the evolution of home mortgage finance during that decade. It then examines the collapse of house prices and increase in mortgage defaults during the 1930s and describes how the federal government responded to the wave of home mortgage defaults during the Depression. Although the article summarizes each of the major initiatives, it focuses primarily on the activities of the HOLC, which was the principal vehicle by which the federal government sought to resolve delinquent home mortgages. The HOLC has been cited as a model for how the government could resolve the current wave of mortgage defaults. However, as this article points out, the conditions under which the HOLC operated were quite different from those present today and, hence, the lessons from the operation of the HOLC for the current episode are somewhat limited.

\section{THE HOUSING BOOM AND BUST}

The recent downturn in U.S. house prices and construction was preceded by a period of rapid growth. Between January 2003 and December 2005, single-family housing starts increased at an average annual rate of 8.5 percent. By contrast, between January 2006 and December 2007, housing starts fell at an average annual rate of 21.8 percent. ${ }^{6}$ The U.S. experienced a similar boom/ bust cycle in housing construction during the 1920s and early 1930s. Annual data for 1900-41 on the number of single-family housing starts are shown in Figure 1, alongside data on the value

\footnotetext{
6 The data reported on housing starts are averages of monthly yearover-year percentage changes. The source of these data is the Department of Commerce (Haver Analytics).
} 


\section{Figure 1}

\section{Single-Family Housing Starts and Value of New Units, 1900-41}

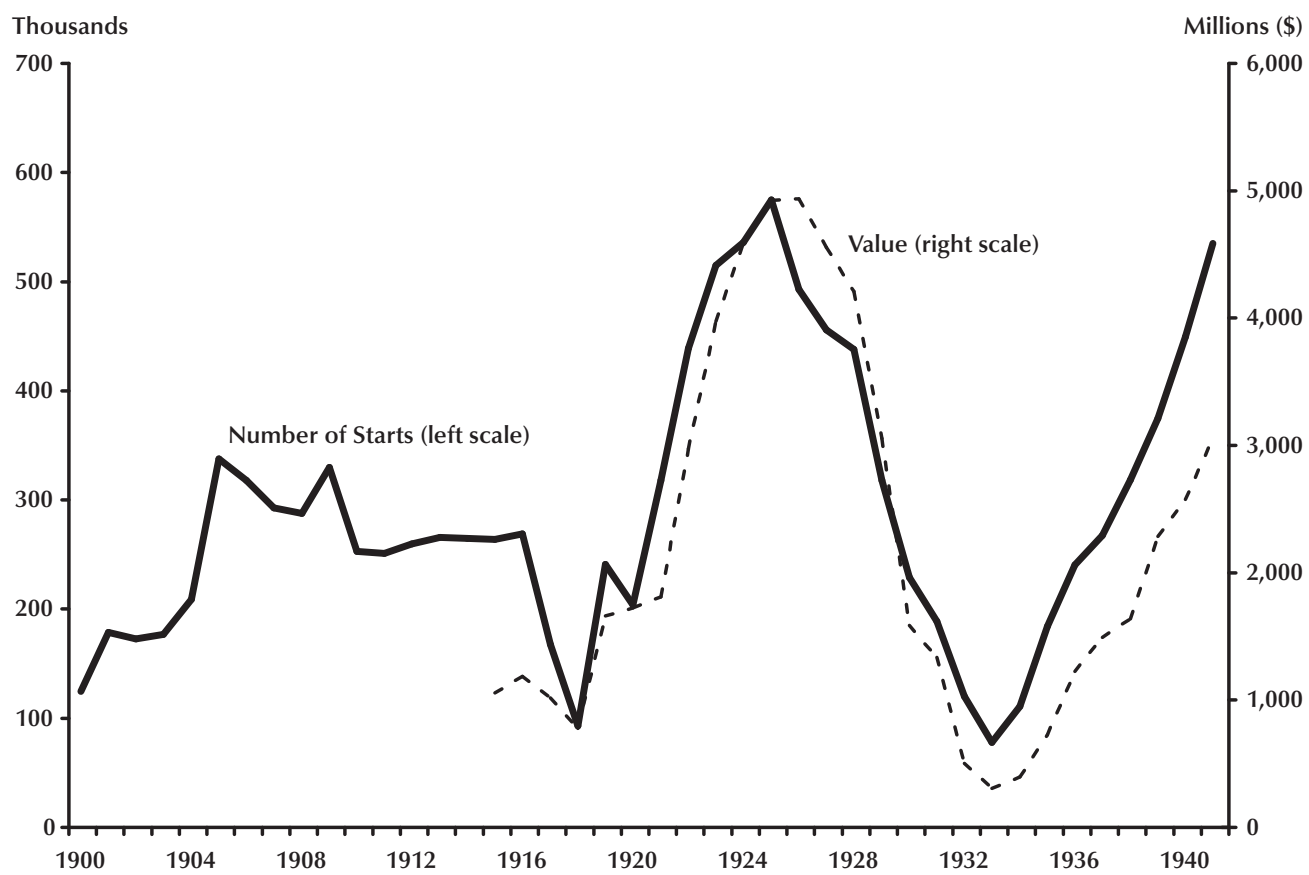

of new single-family housing units (from 1915, when data are first available, to 1941$).{ }^{7}$ Construction of new single- and multi-family housing stalled during World War I and, after a brief recovery, slumped again during a recession in 1920-21. ${ }^{8}$ Construction rebounded rapidly as the economy recovered, however, with peaks in single- and multi-family home construction reached in 1925 and 1927, respectively. Some authors have argued that the growth in housing investment during the 1920s outstripped demand. The infamous Florida land and construction boom, which ended with a hurricane in September 1926, is the most-often cited occurrence of a housing bubble. ${ }^{9}$ However,

\footnotetext{
7 Historical Statistics of the United States, Earliest Times to the Present: Millennial Edition (Cambridge University Press, 2006), series Dc511 and Dc257.

8 According to Doan (1997, pp. 27-28), housing starts were at their lowest level since the 1870s during World War I and the 1920 recession, resulting in a severe housing shortage and rapidly rising rents.

9 See, for example, Allen (1957, Chap. 11).
}

many authors contend that real estate speculation was widespread, fueled by lax lending standards and the ease with which securities could be sold to finance construction (e.g., Gordon, 1974, p. 35).

Interest rates began to rise in 1928 when the Federal Reserve tightened monetary policy to stem speculative activity, especially in the stock market, and housing investment began to fall. Housing starts plunged sharply after the business cycle peak in mid-1929. Some authors contend that the decline in housing investment in 1928-29 contributed to the onset of the Great Depression, though that view is not widely held today. ${ }^{10}$

House prices, shown in Figure 2, followed a path that was similar to that of construction.

\footnotetext{
${ }^{10}$ Although Hickman (1960, pp. 320-21) and Gordon (1974, pp. 70-71) link the onset of the Depression to the downturn in housing investment, most recent studies attribute the onset of the Depression either to restrictive monetary policy (e.g., Friedman and Schwartz, 1963; Hamilton, 1987) or an unspecified adverse technology shock (e.g., Cole and Ohanian, 1999). See Parker (2007) for a survey of recent research on the causes of the Great Depression.
} 
Figure 2

Housing Price Index, 1900-34

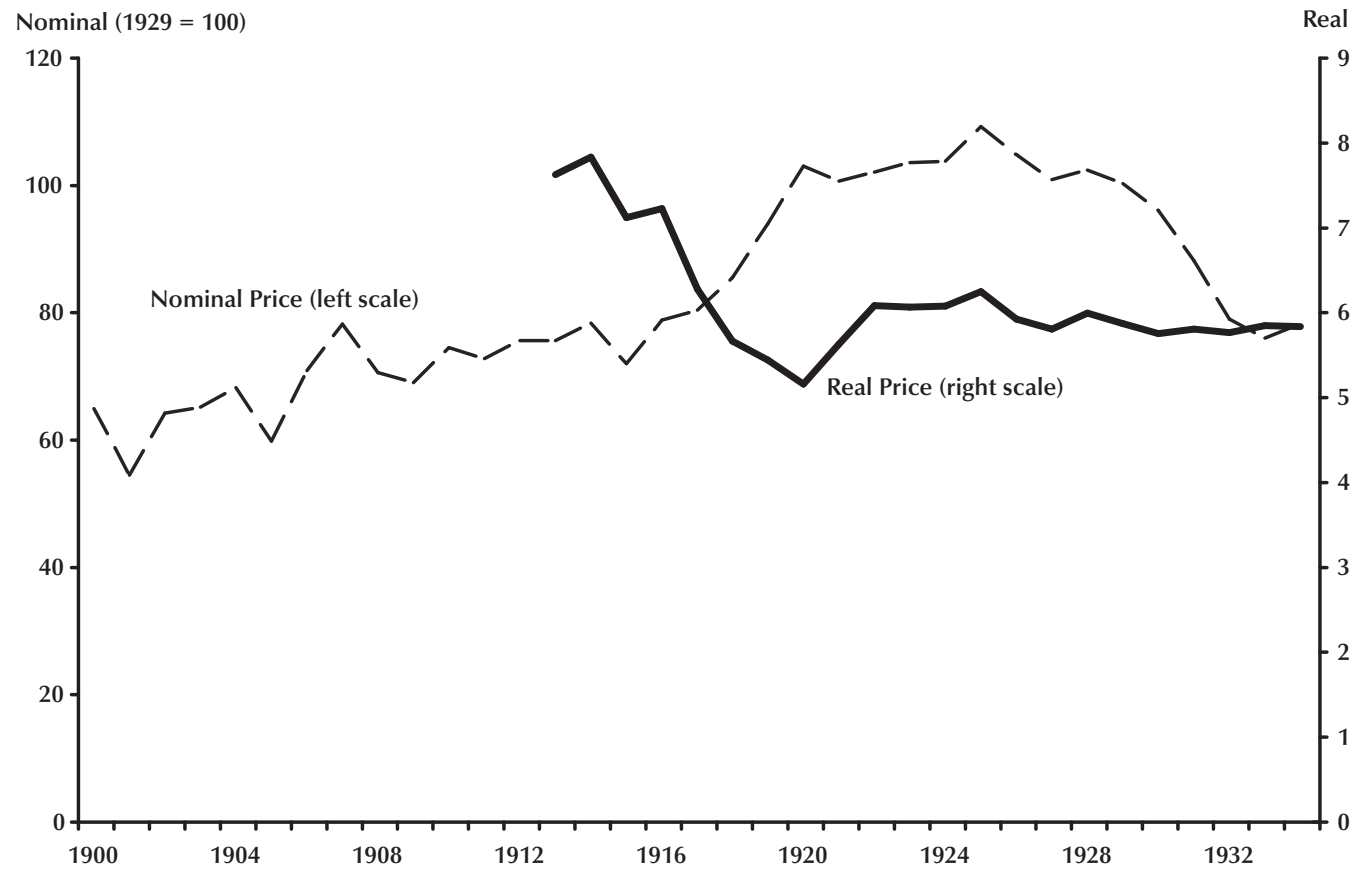

Figure 3

\section{Mortgage Debt Outstanding}

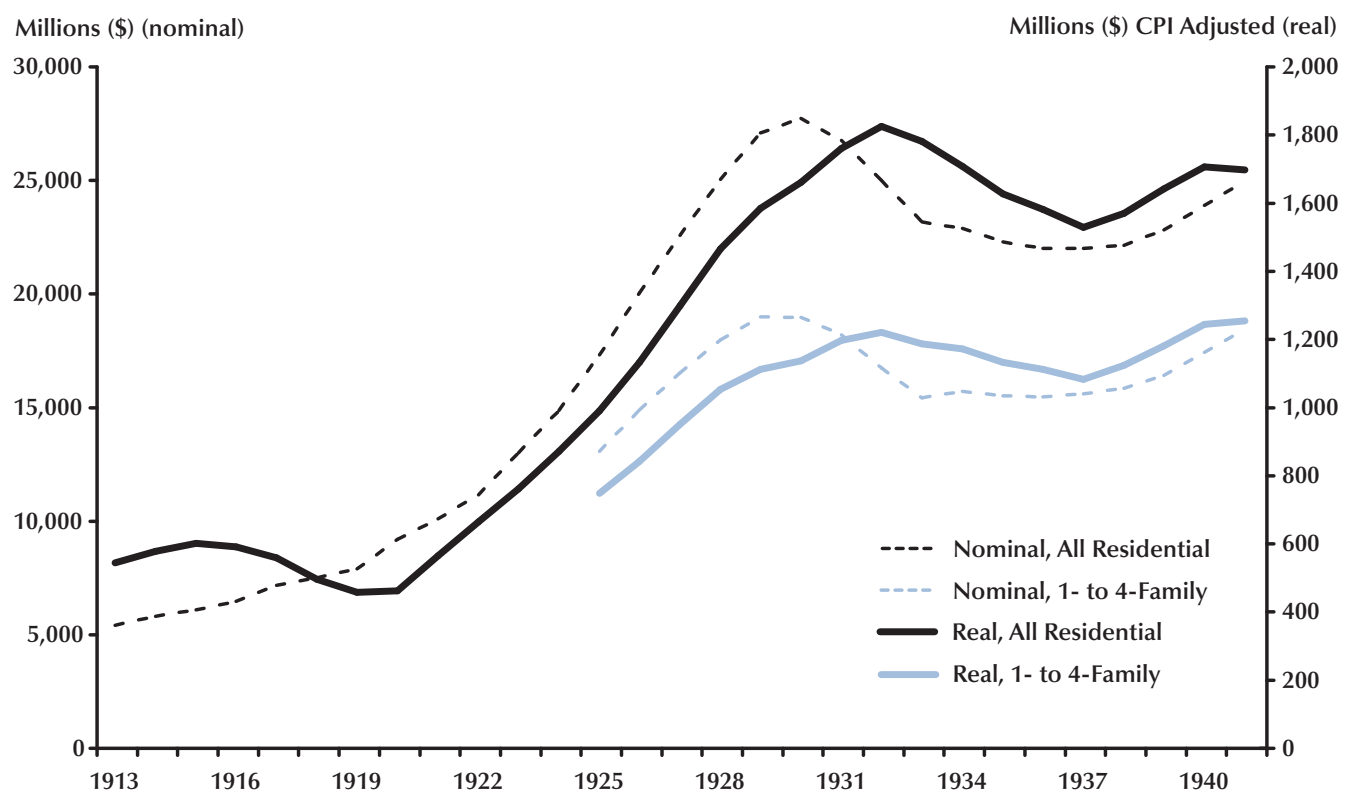




\section{Figure 4}

\section{Nonfarm Residential Mortgage Debt as a Percentage of Nonfarm Residential Wealth}

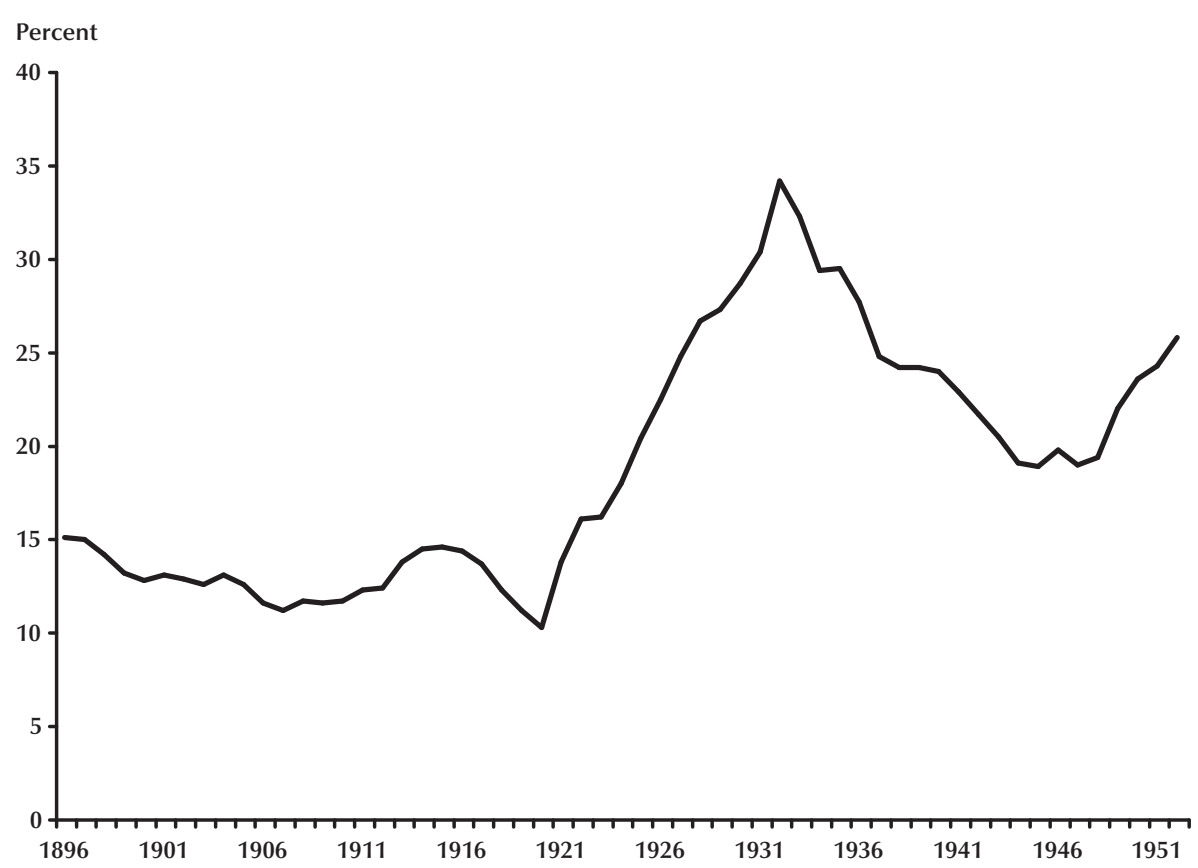

SOURCE: Grebler, Blank, and Winnick, 1956. Table L-6.

In the aggregate, house prices rose to a peak in 1925; then, after declining slowly, prices fell sharply as the Depression took hold. The decline in house prices during 1929-33 was comparable to the decline in consumer prices, however; thus, inflation-adjusted (i.e., real) house prices, also shown in Figure 2, changed little. ${ }^{11}$

Home mortgage debt outstanding increased rapidly during the 1920s and continued to grow even after housing starts had begun to decline and house prices had leveled off. Figure 3 plots the dollar value of outstanding mortgage debt on all residential properties from 1900 to 1941 and on 1- to 4-family properties from 1925 to 1941. (Data for 1- to 4-family properties are not available before 1925.) Data on the real value of outstanding mortgage debt are also shown in the figure.

${ }^{11}$ The nominal house price index data shown in Figure 2 are series Dc826 from Historical Statistics of the United States, Earliest Times to the Present: Millennial Edition (2006). The real price index is the nominal index divided by the consumer price index $(1982-84=100)$.
Although the nominal value of mortgage debt peaked in 1930 and then declined, deflation caused the real value of outstanding mortgage debt to continue to rise until 1932. Thus, consistent with Fisher's (1933) classic "debt-deflation" theory, the burden of outstanding mortgage debt increased sharply during the contraction phase of the Great Depression and economic recovery did not begin until the real value of outstanding debt had begun to decline. ${ }^{12}$

A rising level of debt does not necessarily pose a problem for households, so long as household incomes and wealth are sufficient to make loan payments. However, household incomes and wealth declined rapidly during the Depression. Moreover, falling house prices made it less likely that a homeowner who was having difficulty making his mortgage payments could sell his property

\footnotetext{
12 The NBER identifies the business cycle trough as being in the first quarter of 1933. See www.nber.org/cycles/cyclesmain.html.
} 
for more than the outstanding balance on his loan. From 1929 to 1932, personal disposable income and nonfarm residential wealth fell 41.0 percent and 25.7 percent, respectively, whereas the value of nonfarm residential debt declined by just 6.8 percent. As shown in Figure 4, relative to nonfarm residential wealth, residential mortgage debt outstanding increased sharply throughout the 1920s and continued to rise until $1932 .{ }^{13}$ Thus, as residential property became increasingly leveraged during the 1920s, the declines in household incomes and wealth after 1929 made servicing that debt especially difficult for homeowners.

The rapid increases in building activity, house prices, and mortgage debt during the 1920s are characteristics shared with the recent U.S. housing boom. The 1920s witnessed an increase in loan-to-value ratios and frequent use of high interest rate secondary loans, which is also reminiscent of the recent experience (Doan, 1997, p. 35; Dovenmuehle, 1965, p. 2). Further, according to some commentators, lending standards in the 1920s were unusually lax (Saulnier, 1956, p. 10). Thus, on the eve of the Great Depression, many homeowners were not well positioned to withstand the substantial decline in income or house prices that would occur over the next three years.

\section{MORTGAGE DISTRESS DURING THE DEPRESSION}

As the U.S. economy contracted, loan delinquencies and foreclosures soared, fueled by falling household incomes and property values. Many home loans had terms of five years or less and often involved no, or only partial, payment of principal before a balloon payment was due when the loan matured or was refinanced. ${ }^{14}$ Refinancing was common and easily accomplished in the

\footnotetext{
${ }^{13}$ Data on personal disposable income are from Historical Statistics of the United States, Earliest Times to the Present: Millennial Edition (2006), series Ca68. Data on nonfarm residential wealth and nonfarm residential mortgage debt are from Grebler, Blank, and Winnick (1956, Table L-6).

${ }^{14}$ Lending terms varied widely across lenders. Although mortgages made by savings and loan associations (S\&Ls) were usually fully amortizing, those made by life insurance companies and commercial banks often included no, or only partial, repayment of principal
}

1920s, an environment of rising incomes and property values, but next to impossible during the Depression. Falling incomes made it increasingly difficult for borrowers to make loan payments or to refinance outstanding loans as they came due. The failure of thousands of banks and other lenders contributed to the difficulty of refinancing, as customer relationships were severed and the costs of credit intermediation rose. ${ }^{15}$

At its worst, in 1933, some 1,000 home loans were foreclosed every day (Fifth Annual Report of the Federal Home Loan Bank Board, 1937, p. 4). Figure 5 plots annual data on the mortgage foreclosure rate from 1926, when data are first available, to 1941. The foreclosure rate increased continuously from 1926 to 1933, then declined slowly over the remainder of the period. The foreclosure rate exceeded 1 percent (10 per 1,000 mortgages) in each year from 1931 to 1935 and did not fall below the rate for the year 1926 until 1941. The rate of foreclosures would likely have been far higher were it not for the moratoria on (and other impediments to) foreclosure imposed by several states (Poteat, 1938), as well as the actions of the federal government to refinance delinquent mortgages, which are discussed later in this article. ${ }^{16}$

A broader measure of home mortgage distress is the rate of mortgages with past due payments. Comprehensive data on mortgage delinquency rates do not exist for the 1930s. However, a study of 22 cities by the Department of Commerce found that, as of January 1, 1934, 43.8 percent of urban, owner-occupied homes on which there was a first mortgage were in default. The study also found that among delinquent loans, the average time that they had been delinquent was 15

\footnotetext{
over the life of the loan and were usually for shorter terms than those made by S\&Ls. See Morton (1956) for more information about the mortgage market and loan characteristics during the 1920s.

${ }^{15}$ Bernanke (1983) argues that financial failures increase the cost of credit intermediation and finds evidence that failures contributed significantly to the decline in output during the Great Depression.

${ }^{16}$ Relative to delinquency rates, foreclosure rates have been far higher during the recent period than they were during the Great Depression. Some analysts contend that mortgage securitization and features of bankruptcy law discourage renegotiation of loan terms as an alternative to foreclosure. See Emmons (2008).
} 


\section{Figure 5}

\section{Nonfarm Real Estate Mortgage Foreclosure Rate, 1926-41}

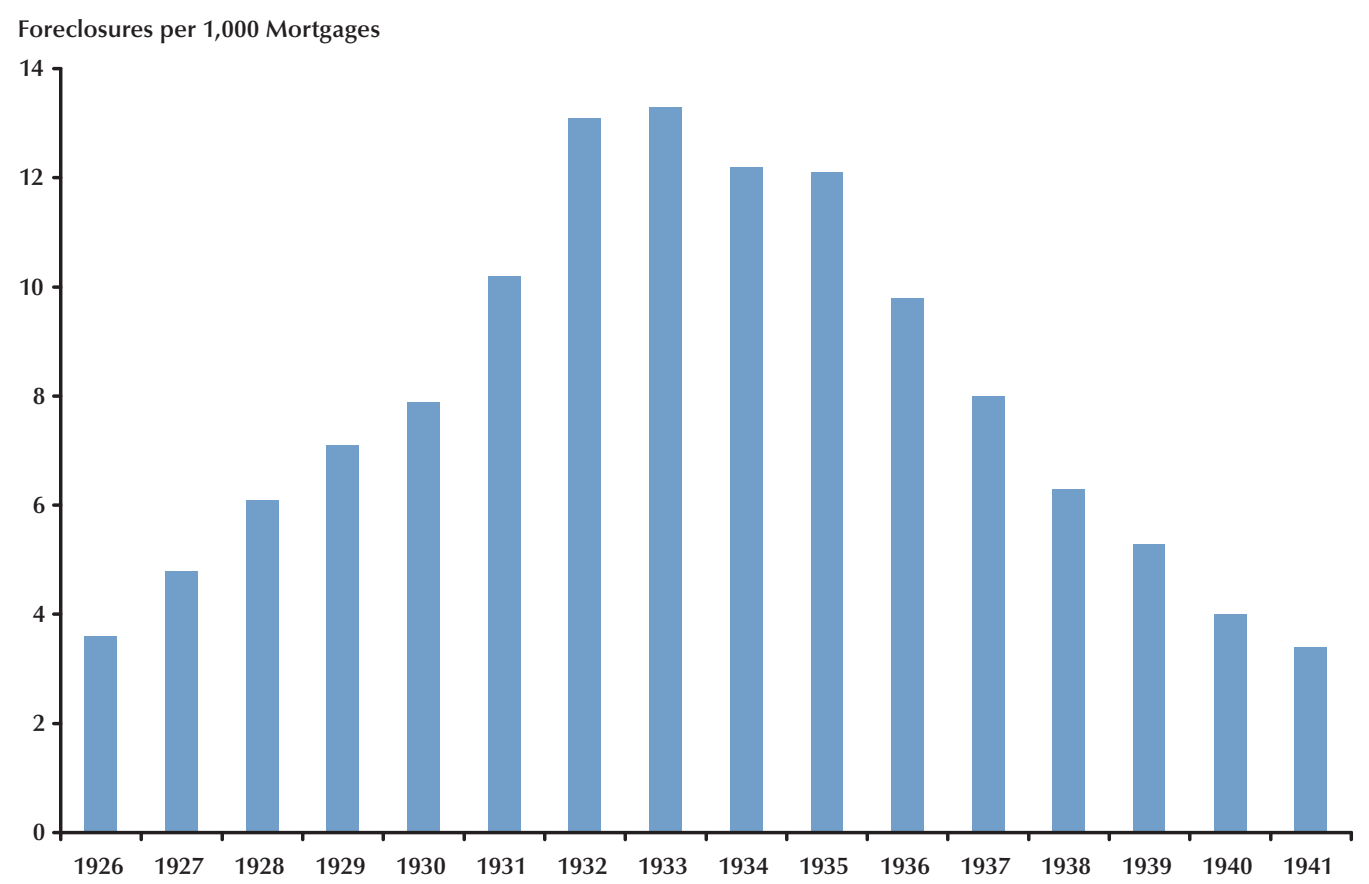

months. Among homes with a second or third mortgage, 54.4 percent were in default and the average time of delinquency was 18 months. Thus, at the beginning of 1934, approximately one-half of urban houses with an outstanding mortgage were in default (Bridewell, 1938, p. 172). For comparison, in the fourth quarter of 2007, 3.6 percent of all U.S. residential mortgages and 20.4 percent of adjustable-rate subprime mortgages had been delinquent for at least 90 days.

Although falling household incomes and house prices were the principal causes of mortgage distress during the Great Depression, lax underwriting may have contributed to the high rate of mortgage delinquency. A National Bureau of Economic Research (NBER) survey found that, during the Depression, foreclosure rates were higher for loans made later in the 1920s than for those made earlier in the decade, suggesting that underwriting standards had deteriorated over time. ${ }^{17}$ Delinquency rates were also higher for non-amortizing and high loan-to-value loans (Morton, 1956, p. 100). Thus, although the proximate cause of the high rate of loan delinquencies and foreclosures during the 1930s was the economic depression, the likelihood of default on any given loan apparently was influenced by the characteristics of the loan itself. ${ }^{18}$

\section{GOVERNMENT TO THE RESCUE}

Federal, state, and local governments took many actions to provide relief from the effects of

${ }^{17}$ Similarly, Demyanyk and Van Hemert (2007) found that the quality of subprime mortgage loans declined monotonically during 2001-06, as the subprime loan market expanded rapidly.

${ }^{18}$ The NBER study found considerable differences in foreclosure rates across lender types, which might reflect differences in typical loan terms, such as amortization or other contract features, between different types of lenders. However, as Morton (1956) acknowledges, the NBER sample of loans was not random. In particular, it did not include data for lenders that failed or otherwise went out of business during the Depression. 


\section{Table 1}

\section{Federal Government Agencies Created in Response to Home Mortgage Distress in the 1930s}

\section{Federal Home Loan Bank System (FHLB)}

- Authorized under Federal Home Loan Bank Act of 1932

- Established 12 regional Federal Home Loan Banks

- Created to provide a stable source of funds to member firms for residential-mortgage and economic-development loans

\section{Home Owners' Loan Corporation (HOLC)}

- Established by the Home Owners' Loan Corporation Act of 1933

- Purchased and refinanced distressed mortgages on 1- to 4-family homes, subject to income and loan qualifications

- Issued over one million loans between August 1933 and June 1936

- Liquidated in 1951

\section{Federal Housing Administration (FHA)}

- Established by the National Housing Act of 1934

- Offers home mortgage insurance on 1- to 4-family homes

- Intended to stabilize mortgage market and improve housing standards and conditions

\section{Federal Savings and Loan Insurance Corporation (FSLIC)}

- Established by the National Housing Act of 1934, administered by FHLB

- Provided deposit insurance for savings and loan associations

- Abolished under Financial Institutions Reform, Recovery and Enforcement Act of 1989

\section{Federal National Mortgage Association (FNMA)}

- Established in 1938 by the Reconstruction Finance Corporation at the request of President Roosevelt

- Created to establish a secondary mortgage market by purchasing FHA-insured loans at par and accrued interest

- 1948 National Housing Act amendment gave FNMA a federal charter to become independent of the RFC; FNMA given authority to purchase FHA and Veterans Administration (VA)-insured loans

- 1968 Chartered by Congress as a government-sponsored private corporation

SOURCE: Annual Report of the Federal Home Loan Bank Board (1933, 1934, 1951), Haar (1960), Harris (1951), Fannie Mae website (www.fanniemae.com/about), and Wallace (1938).

the Great Depression on housing and mortgage markets. For example, 33 states enacted legislation providing relief for those with delinquent mortgages, including 28 states that imposed moratoria on home foreclosures (Poteat, 1938). Many of the federal government's actions to alleviate the Depression affected housing and financial markets directly or indirectly. For example, legislation was enacted to stabilize the banking system and to reform securities market practices. Under the National Industrial Recovery Act of 1933, the federal government established a temporary program for the construction of low-cost housing.
The United States Housing Act of 1937 replaced this program with a system of federal subsidies for local government housing projects (Doan, 1997, pp. 39-42).

In addition to programs aimed at providing affordable housing, the federal government took several steps to alleviate distress in mortgage markets. Table 1 lists the major agencies created during the 1930s to provide liquidity for home lenders, reduce the number of home loan foreclosures, and reform the mortgage market. This section describes the main objectives of each of these agencies. 


\section{Federal Home Loan Bank System and Federal Savings and Loan Insurance Corporation}

The Federal Home Loan Bank System (FHLB) was established in 1932 to provide a federal lender for private institutions that specialize in home mortgage loans, including savings and loan associations (S\&Ls), mutual savings banks, and life insurance companies. FHLB membership was required of all federally chartered S\&Ls and was optional for state-chartered lenders. The system had an initial capitalization of $\$ 125$ million and was patterned after the Federal Reserve System, with 12 regional Home Loan Banks and an oversight Board located in Washington, D.C. Member institutions were required to purchase stock in their local Home Loan Bank and could borrow from the Bank against collateral consisting of mortgages on 1- to 4-family houses or U.S. government securities (or securities fully guaranteed by the U.S. government). Home Loan Bank operations were financed from their capital and deposits of member institutions and by issuing debt. Interest on Home Loan Bank securities was exempt from federal, state, and local income taxes, but the securities were not guaranteed by the U.S. government. ${ }^{19}$

The FHLB began to lend in December 1932; by December 1933, it had over $\$ 85$ million of loans outstanding (Fifth Annual Report of the Federal Home Loan Bank Board, 1937, p. 130). Through 1941, average year-end FHLB advances outstanding ranged from a low of 1.4 percent of total member S\&L assets in 1934 to a high of 3.5 percent in 1933 and $1937 .^{20}$

The Federal Savings and Loan Insurance Corporation (FSLIC) was established by the National Housing Act of 1934 and placed under the supervision of the Federal Home Loan Bank Board. The FSLIC was created to provide federal insurance for savings accounts of up to $\$ 5000$ at

\footnotetext{
${ }^{19}$ See Wallace (1938) for additional information about the organization and operations of the FHLB during the 1930s.

${ }^{20}$ Data on year-end outstanding FHLB advances and total assets of member savings and loan associations are from Historical Statistics of the United States, Earliest Times to the Present: Millennial Edition (2006), series Dc1140 and Cj383, respectively.
}

S\&Ls. Account insurance was mandatory for all federally chartered S\&Ls and optional for statechartered institutions. As with government insurance of commercial bank deposits, federal insurance for S\&Ls was intended to restore the confidence of depositors in the safety of savings accounts and thereby increase the flow of deposits to savings institutions and discourage panic withdrawals. By encouraging growth in savings institution deposits, Congress sought to increase the amount of funds available for home mortgage loans. ${ }^{21}$

\section{Home Owners' Loan Corporation}

The Home Owners' Loan Corporation (HOLC) was created as an agency of the Federal Home Loan Bank Board by an act of Congress in 1933. The HOLC was authorized for a period of three years to purchase and refinance delinquent home mortgages, including mortgages on properties that had recently been foreclosed on. The HOLC had an initial capitalization of $\$ 200$ million and was authorized to issue up to $\$ 2$ billion (later increased to $\$ 4.75$ billion) of bonds to purchase mortgages on 1- to 4-family properties that were in default or that had resulted in foreclosure during the previous 24 months. Interest on securities issued by the HOLC was exempt from federal, state, and local income taxes, and the payment of interest was guaranteed by the federal government. ${ }^{22}$

The HOLC was permitted to acquire delinquent mortgages on properties with an appraised value of up to $\$ 20,000 .^{23}$ HOLC loans were limited to 80 percent of the appraised value of the underlying property or a maximum of $\$ 14,000$, whichever was less. The HOLC sometimes permitted junior liens (second mortgages) on properties against which it held the first mortgage, but refused to permit the total obligations on a prop-

\footnotetext{
${ }^{21}$ See Wallace (1938) for additional information.

${ }^{22}$ A 1934 amendment extended the government guarantee to the principal on HOLC bonds. See Harriss (1951, pp. 152-56) for information about HOLC borrowing operations.

${ }^{23}$ For comparison, $\$ 20,000$ in 1933 prices is equivalent to approximately $\$ 320,000$ in 2007 prices, as adjusted by the consumer price index.
} 
erty to exceed 100 percent of the appraised value. Further, the HOLC made loans only to those homeowners it deemed likely to have sufficient income to make their loan payments (Home Owners' Loan Corporation, 1936, p. 10). Nearly half of the loan applications received by the HOLC were rejected or withdrawn (Harriss, 1951, p. 1). Although many home loans at the time were short-term loans with little or no amortization of principal, the HOLC restructured the loans it acquired as 15-year, amortizing loans at a fixed maximum interest rate of 5 percent. ${ }^{24}$

The HOLC was authorized to conduct its own property appraisals and did so based on three considerations: (i) market value at the time of the appraisal, (ii) the cost of a similar plot of land at the time of the appraisal plus the reproduction cost of the building minus depreciation, and (iii) the value of the premises, by capitalizing the reasonable monthly rental value over a 10year period immediately preceding the appraisal date (Harriss, 1951, p. 41). Harriss (1951, pp. 4142) reports that appraisals were often generous, reflecting more the appraiser's view about the long-run value of a property than its current, depressed value.

Although private lenders from whom the HOLC purchased loans often suffered a loss on the nominal value of their original loans, the HOLC's liberal appraisals ensured that lenders preferred to sell many delinquent loans to the HOLC rather than attempt to recoup their losses through foreclosure. Between August 1933 and June 1935, the HOLC received nearly 1.9 million loan applications. By June 1936, the HOLC made just over one million loans totaling $\$ 3.1$ billion. For comparison, the value of the private U.S. residential housing stock in 1933 is estimated to have been $\$ 89.7$ billion. ${ }^{25}$ The average HOLC loan amount was $\$ 3,039$, and 75 percent were for less than $\$ 4,000$. By value, the HOLC accounted for 12 percent of all new mortgages on 1 - to 4 -family

\footnotetext{
${ }^{24}$ Initially, interest-only terms were granted for the first three years of a loan. Beginning in 1936, these loans were reamortized as 12year fully amortizing loans (Fourth Annual Report of the Federal Home Loan Bank Board, 1936, p. 30).

${ }^{25}$ Historical Statistics of the United States, Earliest Times to the Present: Millennial Edition (2006), Series Dc55.
}

homes in 1933, 71 percent in 1934, 26 percent in 1935, and just 6 percent in 1936-the last year it accepted applications for new loans. ${ }^{26}$ The HOLC provided refinancing for some 10 percent of all nonfarm, owner-occupied dwellings in the United States and about 20 percent of those carrying a mortgage.

Figures 6 and 7 show the distribution of new and outstanding home mortgages across major groups of lenders for each year from 1925 to 1941. ${ }^{27}$ Although the HOLC did not accept new applications after 1936, it continued to make loans in later years on property that it foreclosed on and later resold. The stock of outstanding mortgage debt held by the HOLC reached a peak in 1935, when it held nearly 19 percent of all mortgage debt outstanding on 1- to 4-family homes. Thereafter, the HOLC share of outstanding debt gradually declined as the economy and private lenders continued to recover. Still, as late as 1941, the HOLC held about 10 percent of the value of outstanding residential mortgage debt.

Of the approximately one million loans made by the HOLC, some 20 percent ended in foreclosure or voluntary transfer of the underlying property to the HOLC. Foreclosures peaked during the recession of 1937-38. The HOLC was not quick to foreclose on delinquent loans, being "as considerate of delinquent but deserving borrowers as its responsibility to the Federal Government and the taxpaying public will permit" (Third Annual Report of the Federal Home Loan Bank Board, 1935, p. 600). The HOLC often counseled delinquent borrowers and readjusted payment schedules rather than moving quickly to foreclosure when borrowers fell behind on their payments. On average, HOLC loans were delinquent for two years before foreclosure (Harriss, 1951, p. 73).

\footnotetext{
${ }^{26}$ Historical Statistics of the United States, Earliest Times to the Present: Millennial Edition (2006), series Dc983-989.

${ }^{27}$ In the figures, institutional lenders include commercial banks, mutual savings banks, S\&Ls, insurance companies, the Federal National Mortgage Association, and other institutional lenders. Non-institutional lenders include individuals, mortgage brokers, construction companies, trust departments of commercial banks, and others. Data for new and outstanding mortgages are from Historical Statistics of the United States, Earliest Times to the Present: Millennial Edition (2006), series Dc983-989 and series Dc914-921, respectively.
} 
Figure 6

\section{Share of New Mortgages by Lender}

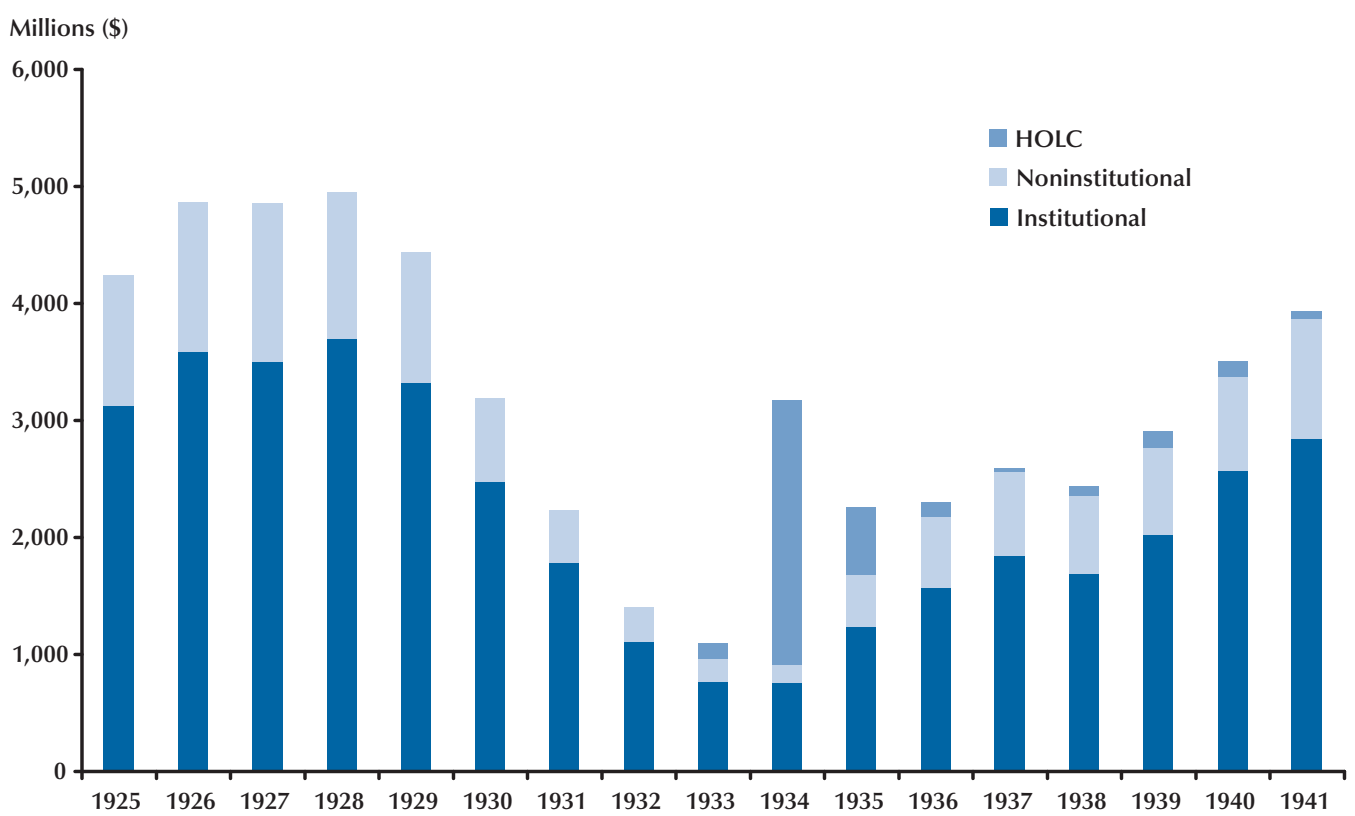

SOURCE: Historical Statistics of the United States, series DC983-989.

\section{Figure 7}

\section{Outstanding Mortgage Debt by Lender, 1925-41}

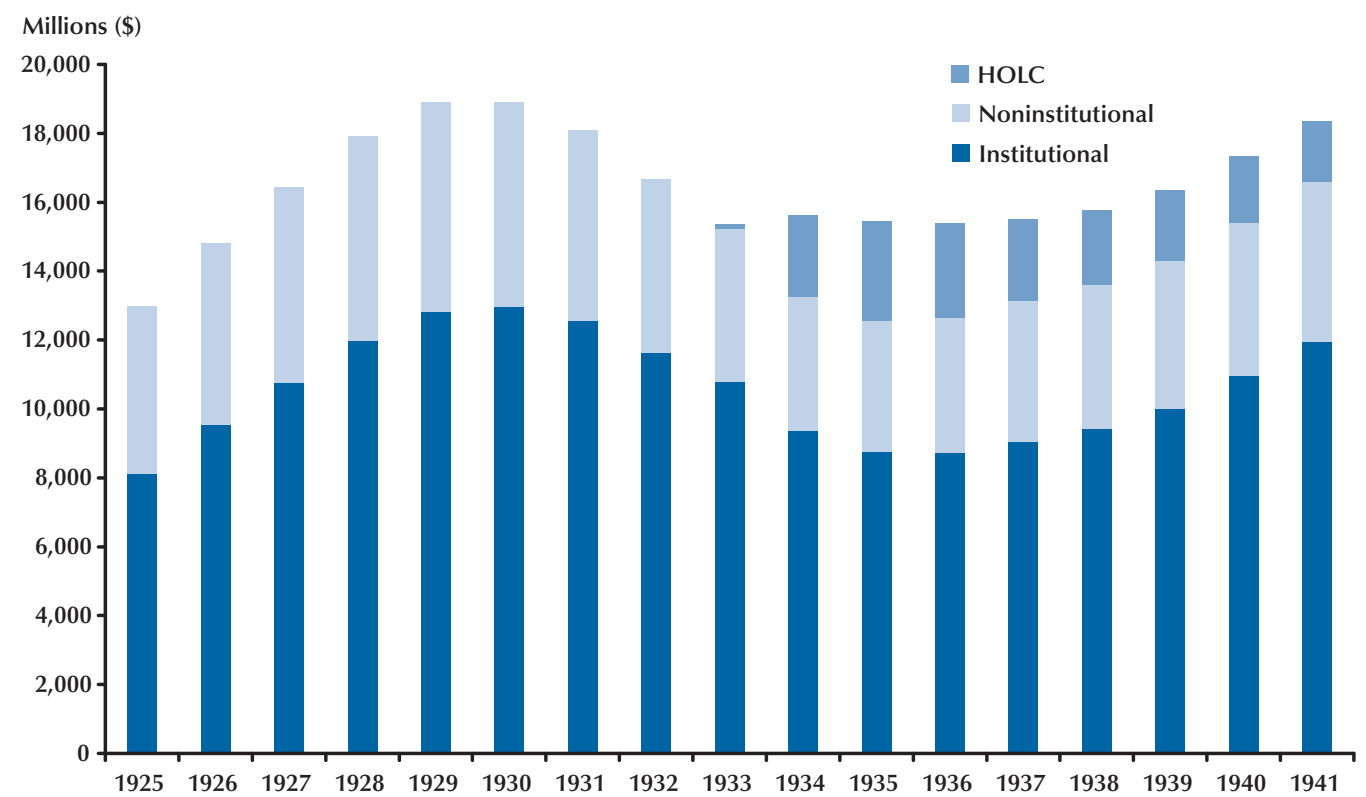


Because the HOLC refinanced distressed loans, its foreclosure rate was higher than that of other lenders. For example, the foreclosure rate on loans made by life insurance companies during 1933-36 was a mere 2.6 percent, compared with nearly 20 percent for the HOLC (Harriss, 1951, p. 71). The limitation that HOLC loans not exceed 80 percent of a property's appraised value probably held down the agency's foreclosure rate, as did its policy of lending only to those borrowers who had a reasonable prospect of being able to service their loan. Furthermore, most HOLC loans were made somewhat after the trough of the business cycle, and rising household incomes helped to limit loan default rates.

It is difficult to determine the extent to which the HOLC contributed to a rebound in the housing market, let alone to the macroeconomic recovery. One study of county-level data found little association between HOLC lending and changes in housing values or homeownership rates between 1930 and 1940 (Fishback, Horrace, and Kantor, 2001). Nevertheless, in helping to clear a million delinquent loans from the books of private lenders, the HOLC undoubtedly contributed to the resumption of private mortgage lending.

The HOLC was liquidated in 1951. After 1936, the bulk of its activities consisted of managing the loans it had made during 1933-36, disposing of property acquired through foreclosure-including making new loans to assist in that processand funding its operations. The HOLC never received a Congressional appropriation other than its initial $\$ 200$ million capitalization. ${ }^{28}$ HOLC loans were funded by the agency's bond issues and operating income (interest, property rental income, etc.). Over its life, the HOLC had a net cumulative operating income of $\$ 352$ million, against a cumulative capital loss of $\$ 338$ million, principally from defaults on mortgage loans it had made. While the rapid growth in household incomes and property values from the mid-1930s through the 1940s held down the default rate on HOLC loans, falling interest rates

\footnotetext{
${ }^{28}$ Like other government agencies, however, the HOLC received free government services, such as free use of the postal system, and was exempt from paying Social Security taxes and overtime wages (Harriss, 1951, p. 161).
}

reduced the HOLC's cost of funds, thereby boosting its profit margin on outstanding loans. ${ }^{29}$

\section{Federal Housing Administration and Federal National Mortgage Association}

The National Housing Act of 1934 created the FHA to administer a federal mortgage insurance program. The program offered insurance to approved private lenders on qualifying loans for the purchase, repair, expansion, or alteration of existing houses and for the construction of new houses. Most FHA-insured loans were required to be fully amortizing, with a maximum interest rate of 5 percent. When the program began, FHAinsured loans were limited to $\$ 16,000$ or less (as compared with a median U.S. house price of $\$ 5,304$ ) and a maximum loan-to-value ratio of 80 percent. A 1938 amendment permitted the FHA to extend insurance to mortgages with loan-tovalue ratios of 90 percent on new homes with mortgages of no more than $\$ 5,400$ (Carliner, 1998, p. 306). ${ }^{30}$ The FHA offered mortgage insurance both for single-family houses and rental projects. The FHA was authorized to charge an annual insurance premium of between 0.5 and 1.0 percent of the outstanding loan principal.

Figure 8 plots annual data for 1935-41 on the dollar amount of new FHA-insured mortgages on 1- to 4-family houses and the share of all new home mortgages insured by the FHA. Private lenders were not quick to embrace FHA insurance because of the requirements imposed on FHAinsured loans, including full amortization and maximum loan interest rates and fees. By 1938, FHA-insured loans still represented less than 20 percent of all new mortgage originations.

In addition to creating the FHA and the FSLIC, the National Housing Act of 1934 authorized the creation of national mortgage associations, which

\footnotetext{
${ }^{29}$ The HOLC issued both short-term debt and callable long-term bonds. The average interest rate paid by the HOLC on its outstanding debt fell from 3.6 percent in 1934 to 2.1 percent in 1939, and to 1.1 percent in 1945-49 (Harriss, 1951, pp. 152-56). HOLC loans carried a contract interest rate of 5 percent, which was reduced for all borrowers to 4.5 percent in October 1939 (Harriss, 1951, p. 5).

${ }^{30}$ Initially, loans for repairs, expansion, or alterations of an existing house were capped at $\$ 2,000$. By 1938 , the cap was raised to $\$ 10,000$. See Wallace (1938) for details about the original provisions associated with FHA insurance and changes made by 1938.
} 


\section{Figure 8}

\section{FHA Insured Mortgages by Dollar Amount, 1935-41}

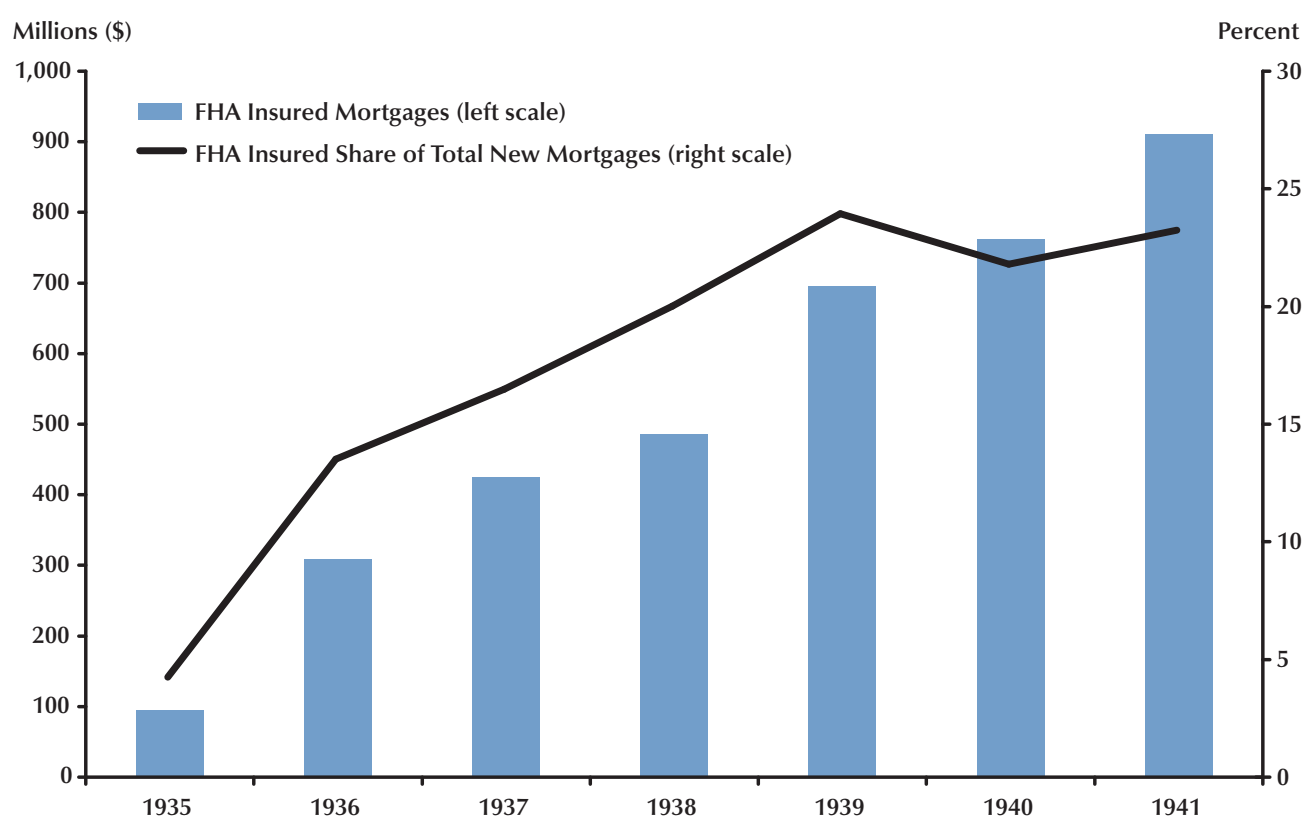

were intended to be federally chartered private organization that bought and sold qualifying first mortgages. This provision of the National Housing Act was intended to promote a liquid national market for mortgages and thereby mobilize capital for housing finance. In fact, no private mortgage associations were formed. However, the Reconstruction Finance Corporation (RFC) established two subsidiaries to purchase FHA-insured mortgages: (i) the RFC Mortgage Company, established in 1935, and (ii) the Federal National Mortgage Association (FNMA), established in 1938. The latter became the principal government purchaser of FHA-insured loans. ${ }^{31}$

The FNMA had an initial capitalization of $\$ 10$ million and was empowered to buy or sell any mortgages insured by the FHA. The agency was authorized to sell bonds to fund its mortgage

\footnotetext{
${ }^{31}$ The Reconstruction Finance Corporation (RFC) was a federal government agency established in 1932 to make loans to banks and other businesses, as well as to state and local governments. The RFC was also authorized to "assist in the reestablishment of a normal mortgage market” (quoted in Haar, 1960, p. 79).
}

purchases; and, although the bonds were not explicitly guaranteed by the federal government, a government guarantee was implicit because the assets of the FNMA were almost entirely invested in FHA-insured mortgages. The FNMA purchased some $\$ 82$ million of mortgages in 1938 and somewhat smaller amounts over the next four years. By the end of 1941, the agency held a \$207 million portfolio of mortgages, which was approximately 1 percent of the total outstanding mortgages on 1- to 4 -family homes at that time. ${ }^{32}$

\section{CONCLUSION}

The recent distress in the U.S. home mortgage market has parallels in the experience of the Great Depression. Like the recent episode, the increase in mortgage defaults during the

\footnotetext{
${ }^{32}$ Data on FNMA purchasers are from Historical Statistics of the United States, Earliest Times to the Present: Millennial Edition (2006), series Dc1146. See Quigley (2006) or Weicher (2006) for information about the activities of the FHA and FNMA since World War II.
} 
Depression coincided with a sharp decline in house prices after a period of rapid gains. Also like the recent experience, mortgage defaults during the Depression were more prevalent on mortgages with unconventional terms, such as short-term, non-amortizing loans. Furthermore, mortgage underwriting standards appear to have deteriorated before the downturn of the 1930s, as they did toward the end of the recent housing boom. However, unlike the recent experience, the main cause of mortgage loan distress during the 1930s was the sharply contracting economy and falling price level. One estimate is that, on January 1, 1934, about half of all mortgages on urban, owner-occupied houses were delinquent. ${ }^{33}$ Not surprisingly, this level of distress prompted numerous local, state, and federal actions to relieve and reform mortgage markets.

The federal government responded to the distress in mortgage markets first by creating a new federal agency, the Federal Home Loan Bank System, to provide a source of loans for mortgage lenders. The federal government then tackled the problem of delinquent loans directly by creating the Home Owners' Loan Corporation, which purchased delinquent loans from their originators. The HOLC purchased some one million loans, which it refinanced as long-term, fixed-rate, amortizing loans payable in monthly installments. Arguably, the HOLC was highly successful. Despite acquiring only delinquent loans, the HOLC ended up foreclosing on fewer than 20 percent of the loans it refinanced. Furthermore, the HOLC operated without a direct taxpayer subsidy (other than its initial $\$ 200$ million capitalization, which it eventually repaid). The HOLC did, however, refuse many loans on the grounds that the borrower lacked the income to make loan payments. The HOLC also loaned no more than 80 percent of the appraised value of the underlying property, though its appraisals were often higher than the current depressed market values. The HOLC also benefited financially from an expanding economy, rising house prices, and falling interest rates, which lowered its funding costs, especially during World War II.

33 Bridewell (1938, p. 172).
The sharp increase in mortgage delinquencies and foreclosures during 2007 prompted numerous calls for government intervention in housing and mortgage markets, including the creation of an HOLC-like agency to purchase delinquent mortgages. The right of lenders to foreclose on collateral is the main reason why the interest rates on secured loans, such as home mortgages, are typically much lower than those on unsecured loans, such as credit card debt. Ordinarily, mortgage foreclosures receive little notice from the public because they have little impact on parties other than the delinquent borrower. However, when the number of foreclosures is high or concentrated geographically, they can lower property values, destabilize neighborhoods, and impose other social costs. Such "externalities" can justify government intervention to reduce the number of foreclosures.

Any government response to mortgage distress would entail some cost. For example, a government purchase of delinquent mortgages, or expanded federal mortgage guarantees or insurance, could impose a substantial monetary cost on taxpayers. Some policies, including a government bailout of delinquent loans or expanded loan guarantees, could also encourage increased financial risk-taking and thereby lead to further instability in the future. Other actions, such as a government-imposed moratorium on loan foreclosures, could simply delay inevitable adjustments that are necessary to restore the functioning of mortgage and housing markets. Such direct government intervention could also increase the cost of loans for future borrowers by encouraging lenders to add a premium to loan interest rates to compensate for the risk that government officials might re-write the terms of loan contracts. ${ }^{34}$

A full assessment of the benefits and costs of government programs to alleviate mortgage distress during the Depression requires further research. There is scant evidence that the acquisition of delinquent mortgages by the HOLC during the 1930s encouraged risky lending. However, the Great Depression experience may not be espe-

\footnotetext{
${ }^{34}$ See Emmons (2008) for more detail on the rationale for government action to reduce foreclosures and discussion of the costs and benefits of specific types of intervention.
} 
cially relevant for addressing how a taxpayer bailout of delinquent borrowers and their lenders would affect behavior today because of differences in the underlying causes of mortgage distress during the two periods. Conceivably, a bailout would more likely encourage risky behavior in the present situation (in which lax underwriting was an important cause of the increase in defaults) than during the Depression (when a sharp decline in economic activity was the main cause of defaults). Thus, while the federal response to mortgage distress during the Great Depression provides insights about how the government might respond to the current wave of defaults, the very different conditions underlying mortgage distress during the two periods warns against drawing strong conclusions from the historical experience for the current episode.

\section{REFERENCES}

Allen, Frederick Lewis. Only Yesterday: An Informal History of the 1920s. New York: Harper and Row, 1957.

Barr, Michael S. Testimony before the United States Senate Committee on Banking, Housing, and Urban Affairs hearing on "Strengthening our Economy: Foreclosure Prevention and Neighborhood Preservation." Washington, DC: January 31, 2008.

Bernanke, Ben S. "Nonmonetary Effects of the Financial Crisis in the Propagation of the Great Depression." American Economic Review, June 1983, 73(3), pp. 257-76.

Bridewell, David A. The Federal Home Loan Bank Board and its Agencies: A History of the Facts Surrounding the Passage of the Creating Legislation, The Establishment and Organization of the Federal Home Loan Bank Board and the Bank System, The Savings and Loan System, The Home Owners' Loan Corporation, and the Federal Savings and Loan Insurance Corporation. Washington, DC: Federal Home Loan Bank Board, 1938.

Carliner, Michael S. "Development of Federal Homeownership 'Policy'.” Housing Policy Debate, 1998, 9(2), pp. 299-321.
Cole, H.L. and Ohanian, Lee E. "The Great Depression in the United States from a Neoclassical Perspective.” Federal Reserve Bank of Minneapolis Quarterly Review, Winter 1999, 23(1), pp. 2-24.

Demyanyk, Yuliya and Van Hemert, Otto. "Understanding the Subprime Mortgage Crisis." Supervisory Policy Analysis Working Paper 2007005, Federal Reserve Bank of St. Louis, December 2007.

Doan, Mason C. American Housing Production 1880 to 2000: A Concise History. Lanham, MA: University Press of America, 1997.

Dovenmuehle, George. "Development of Mortgage Banking," in Robert H. Pease and Lewis O. Kerwood, eds., Mortgage Banking. New York: McGraw Hill, 1965, pp. 1-7.

Emmons, William R. "Policy Options to Address the Mortgage Foreclosure Crisis." Federal Reserve Bank of St. Louis Regional Economist, July 2008 (forthcoming).

Federal Home Loan Bank Board. Annual Report of the Federal Home Loan Bank Board, various years.

Fishback, Price V.; Horrace, William C. and Kantor, Shawn. "The Origins of Modern Housing Finance: The Impact of Federal Housing Programs During the Great Depression.” Working paper, September 2001.

Fisher, Irving. "The Debt-Deflation Theory of Great Depressions.” Econometrica, 1933, 1, pp. 337-57.

Friedman, Milton and Schwartz, Anna J. Monetary History of the United States, 1867-1960. Princeton, NJ: Princeton University Press, 1963.

Gordon, Robert Aaron. Economic Instability and Growth: The American Record. New York: Harper and Row, 1974.

Grebler, Leo; Blank, David and Winnick, Louis. Capital Formation in Residential Real Estate: Trends and Prospects. Princeton, NJ: Princeton University Press, 1956. 
Haar, Charles M. Federal Credit and Private Housing: The Mass Financing Dilemma. New York: McGraw Hill, 1960.

Hamilton, James D. "Monetary Factors in the Great Depression.” Journal of Monetary Economics, March 1987, 19(2), pp. 145-69.

Harriss, C. Lowell. History and Policies of the Home Owners' Loan Corporation. New York: National Bureau of Economic Research, 1951.

Hickman, Bert. Growth and Stability of the Postwar Economy. Menasha, WI: Brookings Institution, 1960.

Home Owners' Loan Corporation. The Blue Book. Second edition. Washington, DC: 1936.

Leonhardt, David. “Be Warned: Mr. Bubble’s Worried Again.” New York Times, August 21, 2005.

Morton, Joseph Edward. Urban Mortgage Lending: Comparative Markets and Experience. Princeton, NJ: Princeton University Press, 1956.

Parker, Randall E. The Economics of the Great Depression: A Twenty-First Century Look Back at the Economics of the Interwar Era. Cheltenham, UK: Edward Elgar, 2007.
Pollock, Alex J. Testimony before the United States Senate Committee on Banking, Housing, and Urban Affairs hearing on "Strengthening our Economy: Foreclosure Prevention and Neighborhood Preservation.” Washington, DC: January 31, 2008.

Poteat, J. Douglass. "State Legislative Relief for the Mortgage Debtor During the Depression." Law and Contemporary Problems, 1938, 5, pp. 517-44.

Saulnier, R.J. Urban Mortgage Lending: Introduction. Princeton, NJ: Princeton University Press, 1956, pp. 3-13.

Quigley, John M. "Federal Credit and Insurance Programs: Housing.” Federal Reserve Bank of St. Louis Review, July/August 2006, 88(4), pp. 1-29.

Wallace, E.S. "Survey of Federal Legislation Affecting Private Home Financing Since 1932." Law and Contemporary Problems, 1938, pp. 481-509.

Weicher, John C. Commentary on "Federal Credit and Insurance Programs: Housing." Federal Reserve Bank of St. Louis Review, July/August 2006, 88(4), pp. 311-21. 